\title{
Recent Advances in the Chemistry of Gold(I) Complexes with C-, N- and S-Donor Ligands Part II: Sulfur Ylide, Hydrosulfido, Sulfido, Trithiocarbonato, Dithiocarbimato and 1,1- Ethylenedithiolato Derivatives
}

\author{
José Vicente, * M Teresa Chicote, M Dolores Abrisqueta, Pablo González-Herrero, and Rita Guerrero \\ Grupo de Quîmica Organometálica, Departamento de Quîmica Inorgánica, Facultad de Quîmica, Universidad de Murcia, \\ Apartado 4021, Murcia, 30071 Spain
}

In these two papers we report the chemistry of gold(I) complexes with $\mathrm{C}_{-}, \mathrm{N}$-, and $\mathrm{S}$-donor ligands, as recently published by our group, and describe some previously unpublished results. In Part $\mathrm{I}$, the synthesis of alkynyl, amino, imino and nitrido gold(I) complexes was reported (1). In this part, we give an account of the synthesis of gold(I) complexes with sulfur-containing ligands such as sulfur ylides, hydrosulfido, sulfido, trithiocarbonato, dithiocarbimato and 1,1-ethylenedithiolato.

\section{INTRODUCTION}

Some gold(I) complexes with S-donor ligands, such as thiomalate, thioglucose or thiopropanol, are amongst the most effective drugs for the treatment of rheumatoid arthritis (2-4). The potential of these gold(I) complexes as antitumoural, antimicrobial, antileishmaniosis and antiHIV 1 agents has been demonstrated (4-10). However, more clinical trials and the design of new gold(I) complexes with S-donor ligands are probably necessary to realize all the possibilities in this area. This paper gives an account of the results we have recently obtained in some reactions designed to prepare new gold(I) complexes with sulfur-containing ligands. As stated previously (1), we are also interested in studying the weak Au‥Au (aurophilic) interactions present in the structure of many gold(I) compounds. To observe such interactions we have prepared complexes containing several gold atoms bonded to the same donor atom or designed ligands whose geometry favours such weak bonding.

We have reported in the first part of this account (1) the use of the 'acac method' (acac = acetylacetonate) based on the general reactions (1) and (2):

$$
\begin{gathered}
{[\mathrm{Au}(\mathrm{acac}) \mathrm{L}]+\mathrm{BH} \rightarrow[\mathrm{Au}(\mathrm{B}) \mathrm{L}]+\mathrm{acacH}} \\
{\left[\mathrm{Au}(\mathrm{acac})_{2}\right]^{-}+2 \mathrm{BH} \rightarrow\left[\mathrm{Au}(\mathrm{B})_{2}\right]^{-}+2 \mathrm{acacH}}
\end{gathered}
$$

These reactions were used to prepare gold(I) complexes with ylide, thiolato, phosphide, bis(diphenylphosphino) methanide or alkyl ligands (11-30). In the present paper we give new examples of the usefulness of this method.

\section{GOLD(I) COMPLEXES WITH SULFUR YLIDE LIGANDS}

The scarcity of gold complexes with sulfur ylide ligands (31-33) contrasts with the abundance of those with their phosphorus analogues $(12,34-41)$. This fact is even more surprising considering the interest in sulfur ylides and their complexes in organic or organometallic chemistry $(42,43)$.

The treatment of $\left[\mathrm{Me}_{3} \mathrm{~S}=\mathrm{O}\right] \mathrm{ClO}_{4}$ with $\left[\mathrm{Au}(\mathrm{acac}) \mathrm{PPh}_{3}\right]$ gives, depending on the molar ratio of the reagents, mononuclear $\left[\mathrm{Au}_{\{}\left\{\mathrm{CH}_{2} \mathrm{~S}-\right.\right.$ 
$\left.\left.(=\mathrm{O}) \mathrm{Me}_{2}\right\}\left(\mathrm{PPh}_{3}\right)\right] \mathrm{ClO}_{4}(\mathbf{1})$ or trinuclear $\left[\left(\mathrm{AuPPh}_{3}\right)_{3^{-}}\right.$ $\left.\left\{\mu_{3}-\mathrm{CS}(=\mathrm{O}) \mathrm{Me}_{2}\right\}\right] \mathrm{ClO}_{4}$ (2) sulfur ylide gold(I) complexes (see Box 1) (17). The 2:1 reaction, intended to produce the dinuclear complex $\left[\left(\mathrm{AuPPh}_{3}\right)_{2}\left\{\mu_{2^{-}}\right.\right.$ CHS $\left.(=\mathrm{O}) \mathrm{Me}_{2}\right\} \mathrm{ClO}_{4}$, also gives the $1: 1(\mathbf{1})$ and $1: 3(2)$ products and the mixture could not be separated.

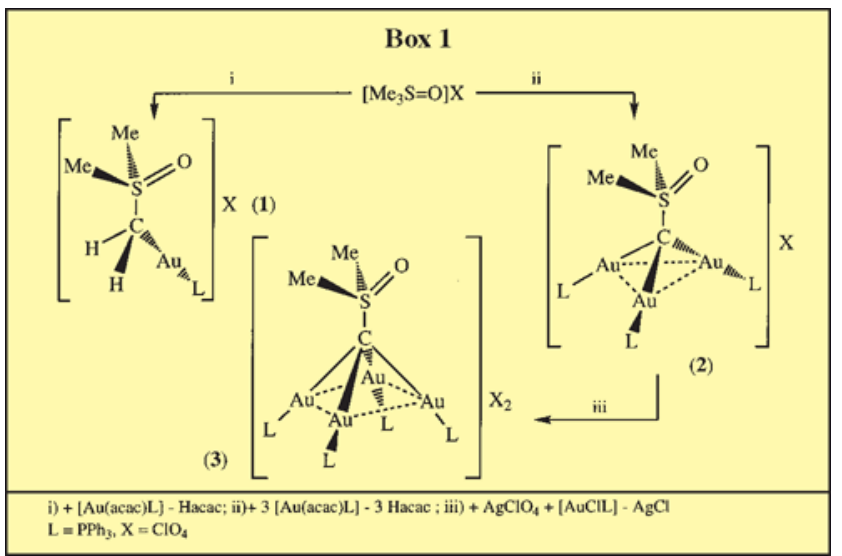

The reaction of 2 with $\mathrm{AgClO}_{4}$ and $\left[\mathrm{AuCl}\left(\mathrm{PPh}_{3}\right)\right]$ produced the first complex containing a hypercoordinate ylidic carbon atom $\left[\left(\mathrm{AuPPh}_{3}\right)_{4}\left\{\boldsymbol{\mu}_{4^{-}}\right.\right.$ $\left.\left.\mathrm{CS}(=\mathrm{O}) \mathrm{Me}_{2}\right\}\right]\left(\mathrm{ClO}_{4}\right)_{2}$ (3) the crystal structure of which shows the ylide carbon atom in a square pyramidal environment with an apical $\mathrm{S}(=\mathrm{O}) \mathrm{Me}_{2}$ group and that the $\mathrm{S}-\mathrm{C}_{\text {ylide }}$ bond distance [1.699(9) $\AA$ ] is significantly shorter than the $\mathrm{S}-\mathrm{C}_{\text {methyl }}$ distances [1.745(11), 1.756(11) $\AA]$. 3 does not react further with $\left[\mathrm{Au}\left(\mathrm{OCMe}_{2}\right)\left(\mathrm{PPh}_{3}\right)\right] \mathrm{ClO}_{4}$ (17). The number of complexes with a clustering of $\mathrm{AuPR}_{3}$ groups around a hypercoordinate carbon atom is limited to homoleptic species containing an interstitial carbon atom, $\left[\left(\mathrm{AuPR}_{3}\right)_{5} \mathrm{C}\right]^{+}$and $\left[\left(\mathrm{AuPR}_{3}\right)_{6} \mathrm{C}\right]^{2+}(44-48)$, tetraauriomethane and -ethanes $\left[\left(\mathrm{AuPR}_{3}\right)_{4} \mathrm{CR}^{\prime}\right]^{+}(\mathrm{R}=\mathrm{alkyl}$, aryl, $\left.\mathrm{R}^{\prime}=\mathrm{H}, \mathrm{Me}\right)(49,50)$ and bis(silyl)methanium cations $\left[\left(\mathrm{AuPPh}_{3}\right)_{3} \mathrm{C}\left(\mathrm{SiR}_{3}\right)_{2}\right]^{+}\left(\mathrm{R}_{3}=\mathrm{Me}_{3}, \mathrm{Me}_{2} \mathrm{Ph}\right)$.

The stepwise metallation of the same methyl group is a remarkable feature attributable to aurophilicity [see Introduction in Part I (1)] (47, 48). If this tendency were not so important one might have expected that, after the first $\mathrm{AuPPh}_{3}$ group had replaced a hydrogen atom in a particular methyl group, further $\mathrm{AuPPh}_{3}$ groups would replace hydrogen atoms of nonmetallated methyl groups; since these methyl groups should be somewhat more acidic, in accord with the weak $+\mathrm{I}$ effect of the $\mathrm{AuPPh}_{3}$ group. The same would be expected on steric grounds. In addition, in the absence of the aurophilic effect one could have expected coordination of the fourth $\mathrm{AuPPh}_{3}$ group to the oxygen atom.

\section{GOLD COMPLEXES WITH S-DONOR LIGANDS}

\section{Hydrosulfido and Sulfido Complexes}

Interest in hydrosulfido complexes stems from the reactivity they exhibit toward organic substrates (51, $52)$, their proposed role as intermediates in important industrial (hydrodesulfurization) (53-55) and biological catalytic processes (56), and their use as models in theoretical studies (57).

It has been suggested that considerable quantities of gold may be transported in hydrothermal ore solutions as $\left[\mathrm{Au}(\mathrm{SH})_{2}\right]^{-}$. Although previous solubility measurements of gold and $\mathrm{Au}_{2} \mathrm{~S}$ in aqueous sulfide or hydrogen sulfide solutions had indicated formation of this complex, it had not been isolated from these solutions (58-63). The reaction of hydrogen sulfide with acetylacetonatogold(I) complexes or with chlorogold(I) complexes in the presence of diethylamine (see Box 2) allowed us to prepare different hydrosulfidogold(I) complexes of the types $\left[\mathrm{Au}(\mathrm{SH})_{2}\right]^{-}$(4) $(14,64),[\mathrm{Au}(\mathrm{SH})(\mathrm{R})]^{-}$(5) (64) $[\mathrm{R}=$ $\left.\mathrm{C}_{6} \mathrm{~F}_{5}, \quad \mathrm{C}_{6} \mathrm{H}_{4} \mathrm{NO}_{2}-2, \quad \mathrm{C}_{6} \mathrm{H}_{2}\left(\mathrm{NO}_{2}\right)_{3}-2,4,6\right] \quad$ and $\left[\{\mathrm{Au}(\mathrm{SH})\}_{2}\left(\mu_{2}-\mathrm{PPh}_{2}\right)\right]^{-}(6)$ (65). These constitute the first family of hydrosulfido complexes of gold and complex $\mathbf{4}$ is the first isolated homoleptic hydrosulfido complex of any transition metal.

The stability of these hydrosulfido complexes increases with the size of the counterions $Q$. Complexes with the smaller cations eliminate $\mathrm{H}_{2} \mathrm{~S}$ with accompanying formation of various sulfidogold complexes such as $\mathrm{Q}_{3} \mathrm{Q}^{\prime}\left[\mathrm{Au}_{12} \mathrm{~S}_{8}\right]$ (65) $\left(\mathrm{Q}=\mathrm{Q}^{\prime}=\mathrm{NPr}_{4}\right.$, $\mathrm{NH}_{2} \mathrm{Et}_{2} ; \mathrm{Q}=\mathrm{NEt}_{4}, \mathrm{Q}^{\prime}=\mathrm{NH}_{2} \mathrm{Et}_{2}$ ) (the $\mathrm{AsPh}_{4}$ salt had been reported previously, (66)) or $\mathrm{Q}_{2}\left[\left\{\mathrm{AuC}_{6} \mathrm{~F}_{5}\right\}_{3}\left(\mu_{3^{-}}\right.\right.$ S)] (Q.7) $\left(\mathrm{Q}=\mathrm{NMe}_{4}, \mathrm{NEt}_{4}\right)$ (64). Salts of 7 with larger cations $\left(\mathrm{Q}=\mathrm{PPN}, \mathrm{NBu}_{4}\right)$ were prepared by reacting $\mathrm{Me}_{4} \mathrm{~N}$.7 with the appropriate $\mathrm{QCl}$ salt.

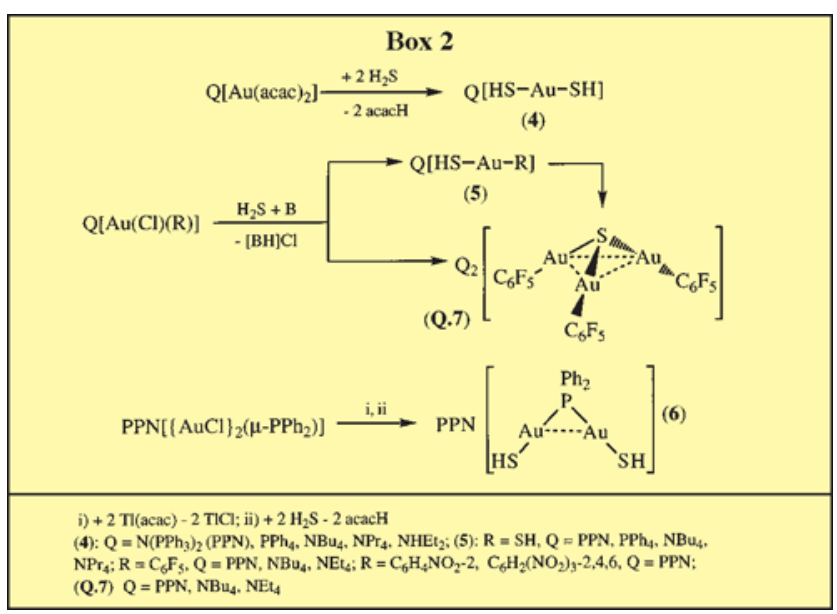




\section{Trithiocarbonato Complexes}

Trithiocarbonates are used as antiwear and antioxidant additives to extreme pressure lubricant oils and greases (67). They are also versatile intermediates for the synthesis of other thio species (68-73). Despite their synthetic and practical utility, however, few trithiocarbonato complexes have been fully characterized.

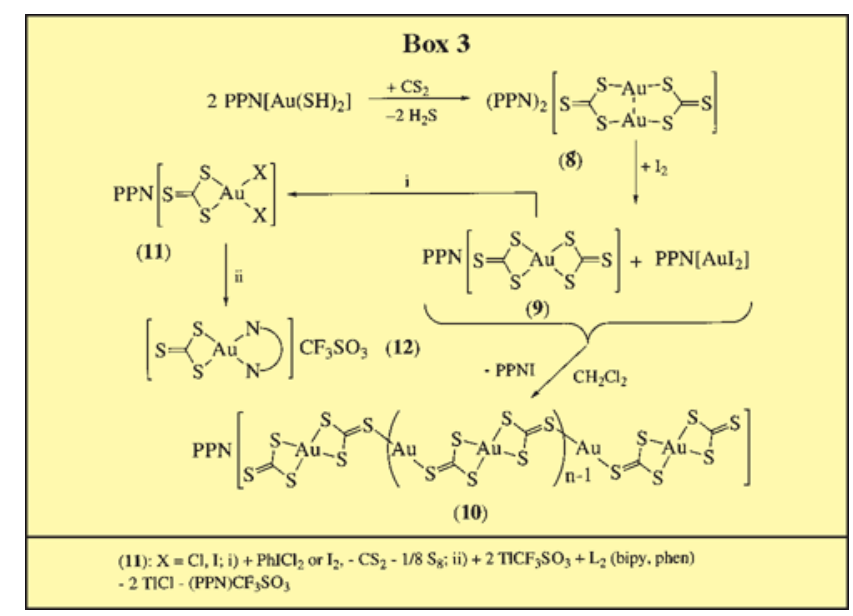

By reacting $\mathrm{PPN}\left[\mathrm{Au}(\mathrm{SH})_{2}\right]$ with $\mathrm{CS}_{2}$ we have prepared PPN $\left[\mathrm{Au}_{2}\left(\mu_{2}-\kappa^{2}-\mathrm{CS}_{3}\right)_{2}\right](\mathbf{8})$, the first complex containing a $\mu_{2}-\kappa^{2}$-bridging $\mathrm{CS}_{3}$ ligand (see Box 3 ). From 8, we have prepared the first family of trithiocarbonato gold complexes (74). The oxidation of 8 with $\mathrm{PhICl}_{2}$ or $\mathrm{I}_{2}$ gives a mixture of $\mathrm{PPN}\left[\mathrm{Au}\left(\mathrm{CS}_{3}\right)_{2}\right]$ (9) and the corresponding $\mathrm{PPN}\left[\mathrm{AuX}_{2}\right]$ salt that can be separated. If not separated, these products react together on standing in dichloromethane to give the polymeric mixed valence complex $\mathrm{PPN}\left[\mathrm{Au}_{n}^{\mathrm{I}}\left\{\mathrm{Au}^{\mathrm{III}}\left(\mathrm{CS}_{3}\right)_{2}\right\}_{n+1}\right]$ (10) (average value of $\mathrm{n}=$ 6) which we have characterized by its reactivity (74). The reaction of 9 with $\mathrm{PhICl}_{2}$ or $\mathrm{I}_{2}$ gives the gold(III) complexes $\mathrm{PPN}\left[\mathrm{AuX}_{2}\left(\mathrm{CS}_{3}\right)\right]$ (11) which in turn react with 2,2'-bipyridine or 1,10-phenanthroline in the presence of $\mathrm{TlCF}_{3} \mathrm{SO}_{3}$ to give the cationic complexes $\left[\mathrm{Au}\left(\mathrm{CS}_{3}\right)(\mathrm{LL})\right] \mathrm{CF}_{3} \mathrm{SO}_{3}(\mathbf{1 2})$.

\section{Dithiocarbimato Complexes}

Insertion reactions of isothiocyanates, as well as other unsaturated molecules, into the $\mathrm{S}-\mathrm{H}$ bond of coordinated hydrosulfido ligands have been described previously (75). The reaction of $\mathrm{PPN}\left[\mathrm{Au}(\mathrm{SH})_{2}\right]$ (4) with the isothiocyanates RNCS (see Box 4) gives complexes with monosubstituted dithiocarbamato ligands $\mathrm{PPN}\left[\mathrm{Au}\left\{\mathrm{SC}(=\mathrm{S}) \mathrm{NHR}_{2}\right]\right.$ (13) (by IR, ${ }^{1} \mathrm{H}$ and ${ }^{19} \mathrm{~F}$ NMR) which we could not isolate in pure form (65). However, those with strong electron-withdrawing $\mathrm{R}$ groups $\left(\mathrm{C}_{6} \mathrm{H}_{4} \mathrm{NO}_{2}-4, \quad \mathrm{C}_{6} \mathrm{~F}_{5}\right)$ react with $\mathrm{PPN}\left[\mathrm{Au}(\mathrm{acac})_{2}\right]$ to give dinuclear dithiocarbimato complexes $(\mathrm{PPN})_{2}\left[\mathrm{Au}_{2}\left(\mu_{2}-\mathrm{k}^{2}-\mathrm{S}_{2} \mathrm{C}=\mathrm{NR}\right)_{2}\right] \quad$ (14) in almost quantitative yields with respect to 4 . Only two gold dithiocarbimato gold complexes $\mathrm{Me}_{4} \mathrm{~N}\left[\mathrm{Au}\left(\mathrm{S}_{2} \mathrm{C}=\mathrm{NCN}\right)_{2}\right],(76)$ and $(\mathrm{PPN})_{2}\left[\mathrm{Au}_{2}\left(\mu_{2}-\boldsymbol{\kappa}^{2}\right.\right.$ $\left.\mathrm{S}_{2} \mathrm{C}=\mathrm{NCN}\right)_{2}$ ] (77) [prepared from $\mathrm{K}_{2}\left(\mathrm{~S}_{2} \mathrm{C}=\mathrm{NCN}\right)$ ] had been described previously.
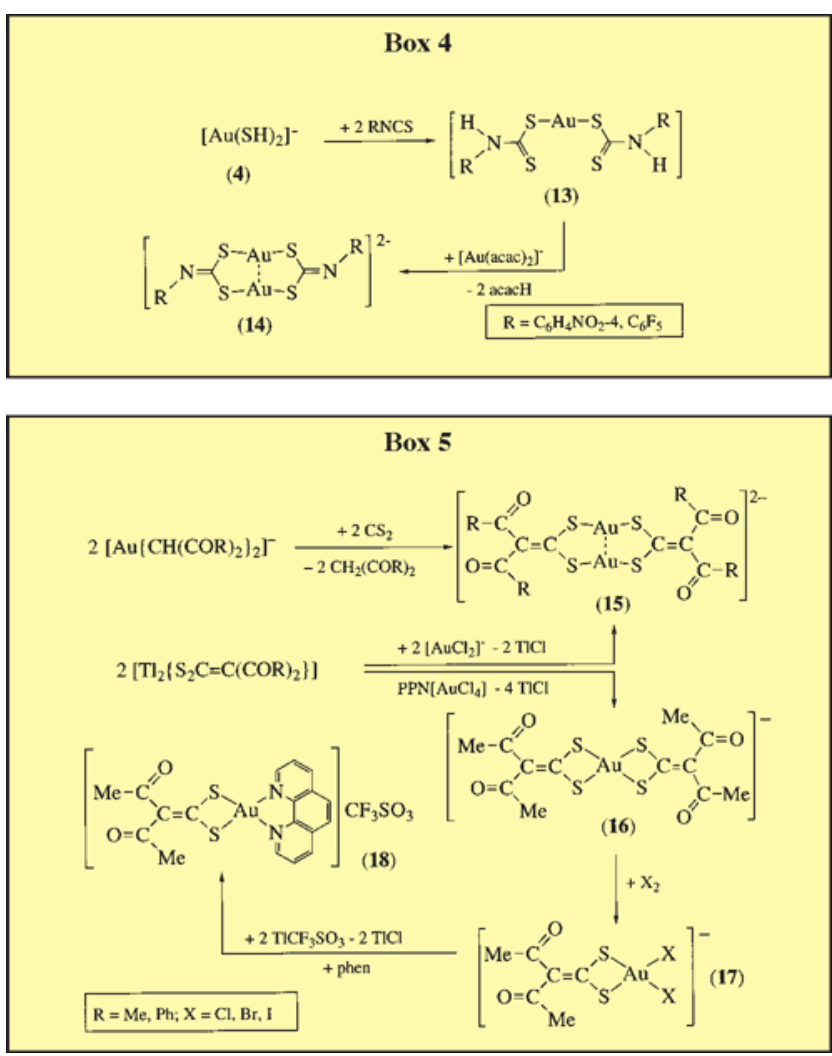

Complexes with 2,2-Diacetyl- and 2,2Dibenzoyl-1,1-ethylenedithiolato ligands

The organometallic $\beta$-diketonato complexes $\mathrm{PPN}\left[\mathrm{Au}\left\{\mathrm{CH}(\mathrm{COR})_{2}\right\}_{2}\right](\mathrm{R}=\mathrm{Me}, \mathrm{Ph})$ react with $\mathrm{CS}_{2}$ to give the complexes $(\mathrm{PPN})_{2}\left[\mathrm{Au}_{2}\left\{\mu_{2}-\kappa^{2}\right.\right.$ $\left.\left.\mathrm{S}_{2} \mathrm{C}=\mathrm{C}(\mathrm{COR})_{2}\right\}_{2}\right]$ (15) (see Box 5) (78). Insertion reactions of $\mathrm{CS}_{2}$ into gold-element bonds are very scarce, and to date only those into the $\mathrm{Au}-\mathrm{C}$ bond in $\left[\mathrm{Au}\left(\eta^{1}-\mathrm{C}_{5} \mathrm{Me}_{5}\right)\left(\mathrm{PR}_{3}\right)\right]$ to give $\left[\mathrm{Au}\left(\boldsymbol{\kappa}^{1-}\right.\right.$ $\left.\left.\mathrm{S}_{2} \mathrm{CC}_{5} \mathrm{Me}_{5}\right)\left(\mathrm{PR}_{3}\right)_{n}\right]\left(\mathrm{R}=\mathrm{Ph}, n=2 ; \mathrm{R}=\mathrm{Pr}^{\mathrm{i}}, n=1\right)(79)$ or into an $\mathrm{Au}-\mathrm{Cl}$ bond of $\left[\mathrm{Au}_{2} \mathrm{Cl}_{6}\right]$ to give $\left[\mathrm{AuCl}_{2}\left(\boldsymbol{\kappa}^{2-}\right.\right.$ $\left.\left.\mathrm{S}_{2} \mathrm{CCl}\right)\right]$ (80) have been described. We have described the insertion of $\mathrm{CS}_{2}$ into an $\mathrm{Au}-\mathrm{S}$ (or $\mathrm{S}-\mathrm{H}$ ) bond in $\operatorname{PPN}\left[\mathrm{Au}(\mathrm{SH})_{2}\right]$ to give $\operatorname{PPN}\left[\mathrm{Au}_{2}\left(\mu_{2}-\kappa^{2}-\mathrm{CS}_{3}\right)_{2}\right]$ (8) (74) (see above). The thallium derivatives $\left[\mathrm{Tl}_{2}\left\{\mathrm{~S}_{2} \mathrm{C}=\mathrm{C}(\mathrm{COR})_{2}\right](\mathrm{R}=\mathrm{Me}, \mathrm{Ph})\right.$ can be obtained by reacting the corresponding $\left[\mathrm{T} 1\left\{\mathrm{CH}(\mathrm{COR})_{2}\right\}\right]$ complexes with $\mathrm{CS}_{2}$. They can be used to prepare $\mathbf{1 5}$ or the gold(III) complex 16. Attempts to prepare gold(II) complexes by oxidative addition of the 
stoichiometric amount of halogen to $\mathbf{1 5}$ failed and only the gold(III) complex $\mathbf{1 6}$ could be isolated. This reacts further with halogen $\left(\mathrm{PhICl}_{2}, \mathrm{Br}_{2}, \mathrm{I}_{2}\right)$ to give mono 1,1-ethylenedithiolato complexes 17 which in turn react with 1,10 -phenanthroline in the presence of $\mathrm{TlCF}_{3} \mathrm{SO}_{3}$ to give cationic complexes $\mathbf{1 8}$.

\section{CONCLUSIONS}

The complexes $\left[\mathrm{Au}(\mathrm{acac}) \mathrm{PPh}_{3}\right]$ and $\left[\mathrm{Au}(\mathrm{acac})_{2}\right]^{-}$are useful starting materials to prepare a number of types of gold(I) complexes. From the first one, we have obtained mono-, tri- and hypercoordinate tetranuclear sulfur ylide gold(I) complexes. The second complex reacts with carbon disulfide to give the 2,2-diacetyl-1,1ethylenedithiolato complexes $\quad\left[\mathrm{Au}_{2}\left\{\mu_{2}-\kappa^{2}\right.\right.$ $\left.\left.\mathrm{S}_{2} \mathrm{C}=\mathrm{C}(\mathrm{COR})_{2}\right\}_{2}\right]^{-}$and with hydrogen sulfide to give $\left[\mathrm{Au}(\mathrm{SH})_{2}\right]^{-}$which reacts with $\mathrm{CS}_{2}$ or RNCS to give trithiocarbonato or dithiocarbimato complexes.

\section{ACKNOWLEDGEMENTS}

The authors wish to express their appreciation to Professor Peter $G$ Jones for solving the crystal structure of many of the complexes reported here and DGES (Spain) for financial support.

\section{ABOUT THE AUTHORS}

Professors María Teresa Chicote and Jose Vicente received their $\mathrm{PhD}$ from Zaragoza University under the supervision of Professor Rafael Usón. They spent the year 1976 in Bristol University where they worked with Professor F Gordon A Stone. Since 1980 they have been at the University of Murcia.

Dr. María Dolores Abrisqueta and Dr. Pablo González Herrero recently received their $\mathrm{PhD}$ degrees from Murcia University and Rita Guerrero is now studying for her $\mathrm{PhD}$. They have been working under the supervision of Professors Vicente and Chicote on the chemistry of gold(I) complexes described in this paper.

\section{REFERENCES}

1 J. Vicente, M.T. Chicote, M.D. Abrisqueta, P. González-Herrero and R. Guerrero, Gold Bull, 1998, 31, 83

2 S.J. Berners-Price and P.J. Sadler, Coord. Chem, Rev., 1996, 151, 1

3 S.P. Fricker, Gold Bull, 1996, 29, 53
4 S.L. Best and P.J. Sadler, Gold Bull., 1996, 29, 87

5 S.P. Fricker, Trans. Met. Chem, 1996, 21, 377

6 M. Viotte, B. Gautheron, M.M. Kubicki, I.E. Nifant'ev and S.P. Fricker, Met-Based Drugs, 1995, 2, 311

7 C.K. Mirabelli, R.K. Johnson, C.M. Sung, L. Faucette, K. Muirhead and S.T. Crooke, Cancer Res, 1985, 45, 32

8 S.Y.M. Chooi, P.H. Leung, K.Y. Sim, K.S. Tan and O.L. Kon, Tetrahedron: Asymmetry, 1994, 5, 49

9 T. Okada, B.K. Patterson, S.Q. Ye and M.E. Gurney, Virology, 1993, 192, 631

10 T.M. Simon, D. H. Kunishima, D.H. Vibert and A. Lorber, Cancer Res, 1981, 41, 94

11 J. Vicente, M.T. Chicote, I. Saura-Llamas and M.C. Lagunas, J. Chem. Soc,, Chem. Commun, 1992, 915

12 J. Vicente, M.T. Chicote and M.C. Lagunas, Inorg. Chem, 1993, 32, 3748

13 J. Vicente, M.T. Chicote and P.G. Jones, Inorg. Chem., 1993, 32, 4960

14 J. Vicente, M.T. Chicote, P. González-Herrero, P.G. Jones and B. Ahrens, Angew. Chem, Int. Ed. Engl, 1994, 33, 1852

15 J. Vicente, M.T. Chicote, P. González-Herrero and P.G. Jones, J. Chem. Soc, Dalton Trans, 1994, 3183

16 J. Vicente, M.T. Chicote, P. González-Herrero and P.G. Jones, J. Chem. Soc., Chem. Commun, 1995,745

17 J. Vicente, M.T. Chicote, R. Guerrero and P.G. Jones, J. Am. Chem. Soc, 1996, 118 699

18 J. Vicente, M.T. Chicote and C. Rubio, Chem. Ber., 1996, 129, 327

19 E.J. Fernández, M.C. Gimeno, P.G. Jones, A. Laguna, M. Laguna and J.M. Lopez de Luzuriaga, Angew. Chem., Int. Ed. Engl, 1994, 33, 87

20 E.J. Fernández, M.C. Gimeno, P.G. Jones, A. Laguna, M. Laguna and J.M. Lopez de Luzuriaga, J. Chem. Soc, Dalton Trans, 1992, 3365

21 M.C. Gimeno, A.Laguna, M.Laguna, F. Sanmartin and P.G. Jones, Organometallics, 1993, 12, 3984

22 M.C. Gimeno, A. Laguna, M. Laguna, F. Sanmartin and P.G. Jones, Organometallics, 1994, 13, 1538

23 J. Vicente, M.T. Chicote, J.A. Cayuelas, J. Fernández-Baeza, P.G. Jones, G.M. Sheldrick and P. Espinet, J. Chem. Soc, Dalton Trans., 1985, 1163

24 J. Vicente, M.T. Chicote, I. Saura-Llamas, J. Turpín and J. Fernández-Baeza, J. Organomet. Chem., 1987, 333, 129

25 J. Vicente, M.T. Chicote, I. Saura-Llamas, P.G. Jones, K. Meyer-Bäse and C.F. Erdbrügger, Organometallics, 1988, 7, 997

26 J. Vicente, M.T. Chicote and I. Saura-Llamas, J. Chem. Soc, Dalton Trans, 1990, 1941

27 J. Vicente, M.T. Chicote, M.C. Lagunas and P.G. Jones, J. Chem. Soc, Dalton Trans, 1991, 2579

28 J. Vicente, M.T. Chicote, M.C. Lagunas and P.G. Jones, J. Chem. Soc, Chem. Commun, 1991, 1730

29 J. Vicente, M.T. Chicote and M.D. Abrisqueta, J. Chem. Soc, Dalton Trans., 1995, 497

30 J. Vicente, M.T. Chicote, R. Guerrero and P.G. Jones, J. Chem. Soc, Dalton Trans. 1995, 1251

31 Y. Yamamoto, Bull. Chem. Soc. Jpn., 1987, 60, 1189

32 I.J.B. Lin, C.W. Liu, L.K. Liu and Y.S. Wen, Organometallics, 1992, 11, 1447

33 J. Stein, J.P. Fackler Jr., C. Paparizos and H..W. Chen, J. Am. Chem. Soc., 1981, 103, 2192

34 W. Kaska, Coord. Chem. Rev., 1983, 48, 1

35 A.W. Johnson, 'Ylides and Imines of Phosphorus', John Wiley and Son, New York, 1993 
36 J.P. Fackler Jr, Polyhedron, 1997, 16, 1

37 H. Schmidbaur, Angew. Chem., Int. Ed. Engl, 1983, 22, 907

38 J. Vicente, M.T. Chicote, M.C. Lagunas, P.G. Jones and B. Ahrens, Inorg. Chem., 1997, 36,4938

39 J. Vicente, M.T. Chicote, M.C. Lagunas, P.G. Jones and E. Bembenek, Organometallics, 1994, 13, 1243

40 D.C. Neitling, R.J. Staples and J.P. Fackler, Inorg. Chim. Acta, 1997, 263, 35, and references therein

41 M. Bardaji, E. Cerrada, P.G. Jones, A. Laguna and M. Laguna, J. Chem. Soc, Dalton Trans, 1997, 2263, and references therein

42 L. Weber, Angew. Chem., Int. Ed. Engl, 1983, 22, 516

43 E.J. Corey and M. Chaykovsky, J. Am. Chem. Soc., 1965, 87, 1353

44 F. Scherbaum, A. Grohmann, G. Müller and H. Schmidbaur, Angew. Chem., Int. Ed. Engl, 1989, 28, 463

45 F. Scherbaum, A. Grohmann, B. Huber, C. Krüger and H. Schmidbaur, Angew. Chem, Int. Ed. Engl, 1988, 27, 1544

46 H. Schmidbaur, B. Brachthauser and O. Steigelmann, Angew. Chem., Int. Ed. Engl., $1991,30,1488$

47 H. Schmidbaur, Gold Bull., 1990, 23, 11

48 O. Steigelmann, P. Bissinger and H. Schmidbaur, Angew. Chem, Int. Ed. Engl, 1990, 29,1399

49 O. Steigelmann, P. Bissinger and H. Schmidbaur, Z. Naturforsch. B, 1993, 48, 72

50 H. Schmidbaur, F.P. Gabbaï, A. Schier and J. Riede, Organometallics, 1995, 14, 4969

51 D. Seyferth, G.B. Womack, R.S. Henderson, M. Cowie and B.W. Hames, Organometallics, 1986, 5, 1568

52 W. Weigand, G. Bosl, C. Robl and J. Kroner, Z. Naturforsch. B, 1993, 48, 627

53 H. Vahrenkamp, Angew. Chem., Int. Ed. Engl., 1975, 14, 322

54 M. Rakowski-Dubois, Chem. Rev., 1989, 89, 1

55 R.J. Angelici, Acc. Chem. Res., 1988, 21, 387

56 D.R. English, D.N. Hendrickson, K.S. Suslick, C.W. Eigenbrot, Jr. and W.R. Scheidt, J. Am. Chem. Soc, 1984, 102, 7258

57 C.J. Adams, M.I. Bruce, M.J. Liddell, B.W. Skelton and A.H. White, J. Chem. Soc., Chem. Commun., 1992, 1314
58 P.J. Renders and T.M. Seward, Geochim. Cosmochim. Acta, 1989, 53, 245

59 D.M. Shenberger and H.L. Barnes, Geochim. Cosmochim. Acta, 1989, 53, 269

60 K. Hayashi and H. Ohmoto, Geochim. Cosmochim. Acta, 1991, 55, 2111

61 H. Colley, Chem. Brit., 1992, 28, 720

62 J.A. Tossell, Geochim. Cosmochim. Acta, 1996, 60, 17

63 L.G. Benning and T.M. Seward, Geochim. Cosmochim. Acta, 1996, 60, 1849

64 J. Vicente, M.T. Chicote, P. González-Herrero, C. Grünwald and P.G. Jones, Organometallics, 1997, 16, 3381

65 J. Vicente, M.T. Chicote and P. González-Herrero, unpublished results

66 G. Marbach and J. Strähle, Angew. Chem., Int. Ed. Engl, 1984, 23, 715

67 J.M. Dumdum, L.T. Mendelson and R.L. Pilling, U.S. Patent 4,908,142 (Chem. Abs, $1990,112,201925 \mathrm{k})$

68 D. Coucouvanis and J.P. Fackler Jr., J. Am. Chem. Soc, 1967, 89, 1346

69 I.B. Benson, J. Hunt, S.A.R. Knox and V. Oliphant, J. Chem. Soc, Dalton Trans, 1978, 1240

70 C. Bianchini, C. Meali, A. Meli and G. Scapacci, J. Chem. Soc, Dalton Trans, 1982, 799

71 C. Bianchini, P. Innocenty and A. Meli, J. Chem. Soc, Dalton Trans, 1983, 1777

72 R. Usón, J. Forniés and M.A. Usón, Syn. React. Inorg. Metal-Org. Chem., 1984, 14, 355

73 J. Forniés, M.A. Usón, J.I. Gil and P.G. Jones, J. Organomet. Chem., 1986, 311, 243

74 J. Vicente, M.T. Chicote, P. González-Herrero and P.G. Jones, Inorg. Chem., 1997, 36, 5735

75 R.J. Angelici and R.G.W. Gingerich, Organometallics, 1983, 2, 89

76 F.A. Cotton and J.A. McCleverty, Inorg. Chem., 1967, 6, 229

77 Z. Assefa, R.J. Staples and J.P. Fackler Jr., Acta Crystallogr., Sect. C, 1995, 51, 2271

78 J. Vicente, M.T. Chicote, P. González-Herrero and P.G. Jones, Chem. Communn., 1997, 2047

79 H. Otto and H. Werner, Chem. Ber, 1987, 120,97

80 D. Jentsch, P.G. Jones, C. Thöne and E. Schwarzmann, J. Chem. Soc., Chem. Commun., 1989,1495

\section{DO YOU WANT TO ADVERTISE IN THIS JOURNAL

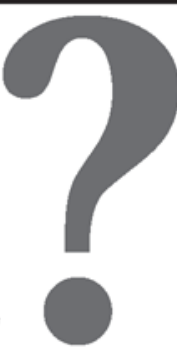

We are considering the introduction of a limited amount of advertising in Gold Bulletin. If you are interested in reaching an international audience of scientists and technologists in academia and industry with an interest in gold, this could be your opportunity.
Interested advertisers should contact the Editor, Dr C.W. Corti, World Gold Council, Kings House, 10 Haymarket, London SW1Y 4BP, England. Tel:+44 1719305171 - Fax: +44171 8396561 E-mail: chris.corti@wgclon.gold.org 